\section{UNIQUE TOOTHBRUSHES FOR INCREDIBLE CAUSES}

Leading provider of oral healthcare products, WhiteWash Laboratories, has teamed up with the Pink Ribbon Foundation and Prostate Cancer UK to offer an exclusive range of pink and black toothbrushes.

These unique pink and black toothbrushes will help to raise support and awareness for both breast cancer and prostate cancer.

By stocking the state-of-the-art toothbrushes from WhiteWash Laboratories you will not only be creating funds for an incredible cause, but will also be providing an exceptional product that can help to maintain your patients' oral health.

The effectively designed manual and rotating toothbrushes feature innovative flossing bristles, which produce an adequate clean every time. They are ergonomically contoured to fit the shape of the hand, thereby creating a more comfortable brushing experience and enabling patients to easily reach and perfectly clean every area.

Raise awareness and save lives - recommend the pink and black toothbrushes from WhiteWash Laboratories today.

For more information call 0844 6869150 or visit www.whitewashlaboratories.com.

To find out more about breast cancer and prostate cancer visit www.pinkribbonfoundation.org.uk or www.prostatecanceruk.org.
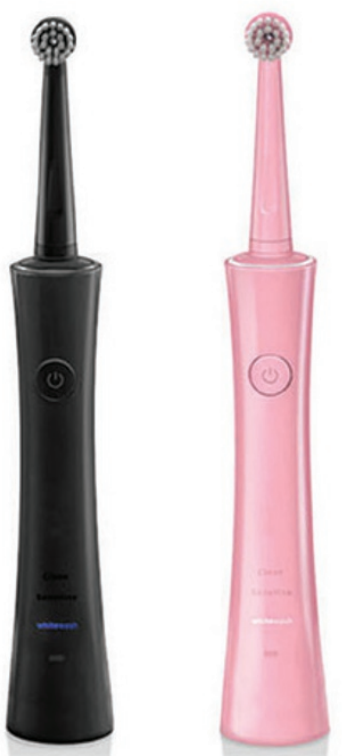

\section{SOLUTIONS TO SUIT EVERY DENTITION}

From everyday essentials such as brushes and mouthwashes to more specialised dental adjuncts such as the handy Tandex Orthodontic and Implant kits, Tandex has a solution to suit every dentition.

You can now discover all the latest deals and promotions from Tandex by visiting and 'liking' its page on Facebook. Simply enter 'Tandex UK' into the Facebook search bar and you will be taken to the page where you can catch up on all the latest information and special offers.

Tandex is committed to providing the very best toothbrushes, oral health adjuncts and customer service in the dental industry and is constantly looking to expand its reach. With over 80 years' experience manufacturing and providing the highest quality products, the team from Tandex are keen to share their knowledge and passion for all aspects of oral health.

For more information on the amazing oral health products on offer and to find out about the latest promotions and innovations, visit the Tandex Facebook page.

For more information on Tandex's range of products, visit www.tandex.dk or visit www. facebook.com/pages/TandexUK/234855250044190?fref=ts.

\title{
REMOVE DEBRIS, STIMULATE GUMS, FIGHT GINGIVITIS
}

Coming to the BigBite - the oral hygiene catalogue from The Dental Directory - are the Doctor's BrushPicks. Exclusive to the November/December issue, the Doctor's BrushPicks are toothpicks for a healthy smile.

The Doctor's BrushPicks will remove food debris, stimulate the gums and help to fight gingivitis. Improved with Plyalene longer-lasting bristles, they are easy and gentle to use. In four convenient varieties, your patients could see an improvement in their oral health in as little as two weeks.
The BigBite offers oral hygiene products at fantastically low prices. Best of all, every item is ready for free next day delivery.

Your patients will love using the Doctor's BrushPicks and the BigBite can help you to expand into the lucrative area of supplying oral hygiene products, as a source of income. Speak to The Dental Directory today to find out how.

Contact The Dental Directory on 0800585 585, or visit www.dental-directory.co.uk.

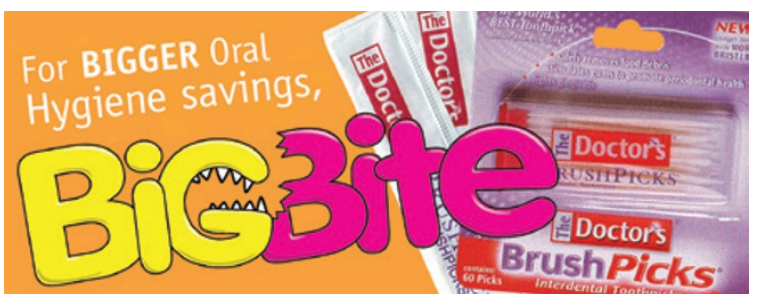

\section{OSCILLATING-ROTATING BRUSHES COME OUT ON TOP AGAIN}

For the third time, the independent, not-for-profit Cochrane Collaboration has concluded that oscillating-rotating technology - used in Oral-B power toothbrushes - is the only type of power brush consistently proven to reduce more plaque and gingivitis versus manual brushing in the short or long term.

The conclusions of this report, published in June 2014, were derived from reviews of 56 studies published from 1964 to 2011 and included seven types of power brush technologies, based on brush head movement. Over 50\% of the studies reviewed focused on oscillating-rotating technology, reinforcing the robustness of Oral-B's body of scientific evidence versus other power brushing technologies.

Additional findings from the report demonstrated that none of the six other power brush technologies considered consistently show significant effects across both outcomes and points in time. The authors concluded that side-toside power brushes (typically marketed as 'sonic') demonstrated 'no significant difference versus manual brushing on plaque or gingivitis reduction in the short or long term'.

The authors also considered evidence regarding the safety of power toothbrushes and found no apparent relationship between the use of power toothbrushes and soft tissue trauma. 